\title{
Pemuda Hijrah: Antara Pietization dengan Lifestyle Pada Komunitas Hijrah Yuk Ngaji Yogyakarta
}

\author{
Irmansyah ${ }^{1}$ \\ ${ }^{1}$ UIN Sunan Kalijaga Yogyakarta \\ email: thegreatirmansyah@gmail.com
}

\begin{abstract}
Abstrak
Perkembangan dunia yang begitu cepat, tidak terlepas dari kemajuan teknologi dan ilmu pengetahun yang terus memberikan inovasi dan kemudahan- kemudahan, kemajuan komunikasi dan informasi menjadi karakteristik utama perkembangan zaman.seiring dengan perkembangan zaman aktifitas dakwah mendapat tantangan tersendiri untuk ikut berkembang, jika dulu berdakwah hanya lewat mimbar, sekarang ini dakwah dapat dilakukan hanya didepan komputer atau smartphone. Dulu gaya berdakwa identik dengan serban dan kain sarung, sekarang menjadi lebih style. Penelitian ini bertujuan untuk mengetahui para pelaku hijrah apakah hijrah membuat mereka semakin shaleh atau hanya sekedar mengikuti gaya hidup yang semakin modren. Penelitian ini menggunakan teori sosial max weber yaitu konsep mendasar pada prilaku manusia yang subjektif, teori tersebut dijadikan sebagai kerangka pemikiran dalam melihat berbagai fenomenologi yang muncul dilapangan. metode yang digunakan dalam penelitian ini adalah kualitatif dengan pendekatan penomenologi. Hasil penelitian ini menunjukkan bahwa gerakan pemuda hijrah dapat memberi dampak positif terhadap generasi muda yang mengikuti komunitas- komunitas hijrah, mereka mengalami perubahan tingkahlaku yang lebih shaleh dan bergaya mengikuti kemajuan zaman namun tetap syar'i.
\end{abstract}

Kata Kunci: Pemuda hijrah, Kesalehan, Gaya hidup

\begin{abstract}
The development of the world is so fast, cannot be separated from advances in technology and science which continue to provide innovation and convenience, advances in communication and information are the main characteristics of the times. Along with the development of the era, da'wah activities have its own challenges to develop, if in the past it was only preaching. through the pulpit, now preaching can be done only in front of a computer or smartphone. In the past, the style was identical to the turban and sarong, now it is becoming more stylish. This study aims to determine whether the doers of Hijrah make them more pious or just follow an increasingly modern lifestyle. This research uses Max Weber's social theory, which is a fundamental concept of subjective human behavior. This theory is used as a framework for seeing the various phenomenologies that arise in the field. The method used in this research is qualitative with a phenomenological approach. The results of this study indicate that the youth movement for hijrah can have a positive impact on the younger generation who follow hijrah communities, they experience changes in behavior that are more pious and stylish following the progress of the times but still syar'i.
\end{abstract}

Keywords: Pemuda hijrah, Piety, Lifestyle

\section{Pendahuluan}

Memasuki era milenial, berbagai macam istilah untuk anak muda disenandungkan, realita yang terjadi seolah menggambarkan apa yang saat ini di alami oleh generasi muda, istilah “ kids Zaman Now” atau “ Generasi Micin” lahir sebaga 
julukan bagi generasi muda yang bergaya hidup serba instan,akrab dengan fenomena kekinian, pergaulan bebas hingga gaya hidup yang hedonisme. (Rais, 2018), seiring dengan hal tersebut munculnya model- model busan yang kekinian juga menambah deretan permasalahan yang cukup kompleks dikalangan remaja, istilah "you can see" menjadi momok yang menggiurkan bagi remaja saat ini.

Pergaulan generasi muda kini dibayang- bayangi oleh kemajuan teknologi serta derasnya perkembangan arus informasi yang nyaris tidak terkendali, selain memiliki nilai positif terhadap kemudahan informasi, kemajuan teknologi juga membawa dampak negatif bagi pergaulan sosial disetiap lapisan masyarakat, dari anak - anak, remaja, dewasa bahkan orangtua sekalipun (Fitri, 2017). oleh karena itu sikap bijak dalam menangani hal itu harus sangat dipokuskan untuk mengantisipasi dampak negatif yang dapat merusak moral generasi muda, khususnya bagi remaja. Remaja menurut world Health Organization (WHO) adalah orang yang berusia antara 10 tahun hingga 24 tahun (Sudargo, 2018). Sedangkan defenisi remaja untuk masyarakat Indonesia yaitu seseorang yang berusia dari umur 11 tahun hingga 20 tahun (Nisfiannoor, 2016).

Masa remaja merupakan masa peralihan antara masa kanak- kanak dan masa dewasa, yang ditandai sejak terjadinya kematangan seksual. Dari sitilah ini remaja sebenarnya tidak memiliki kejelasan tempat, karena ia tidak temasuk dalam golongan anak- anak namun belum dapat diterima sebagai individu dewasa sehingga dapat dikatakan bahwa posisi remaja berada diantara naka- anak dan dewasa, remaja mengalami perkembangan fisik dan sosioemosional yang sangat drastis. Hal ini diartikan bahwa pada masa remaja rentan terjadi goncangan jiwa akibat terjadinya perubahan fisik dan psikologis yang cepat dan drastis pada diri remaja.

Keadaan jiwa dan psikis yang tidak stabil ini mengakibatkan berbagai hal- hal negatif yang bisa mengganggu sikap sosial dan perkembangan remaja. Hal ini diungkapkan dalam artikel Muzayanah, Kenakalan remaja yang terjadi saat ini ditandai dengan krisisnya moral, religiusitas, kontrol diri, pola asuh orang tua dan kekerasan emosional, pokok utama dalam dalam kenakalan remaja ini berkesinambungan dengan hilangnya religiusitas, semakin rendah religiusitas remaja maka semakin meningkat kenakalan remaja (Muzayanah, 2018).

Perkembangan dunia industri ini memunculkan banyak nya spekulasi terhadap berbagai permasalahan yang dihadapi, munculnya berbagai komunitas seperti komunitas, reftil, sosial, otomotif sampai komunitas yang bergerak dalam keagamaan. Yang menjadi perbincangan hangat saat ini tentang komunitas keagamaan salah satunya adalah komunitas hijrah atau yang sering disebut dengan the shift. Gerakan pemuda hijrah ini merupakan sekumpulan para anak muda milenial yang ingin merubah hidupnya dari meninggalkan hal- hal buruk dimasa lalu dan berubah menjadi lebih taat kepada Allah Swt. Jadi pemuda hijrah ini adalah wadah bagi para anak muda yang ingin berhijrah dan ingin lebih mendekatkan dirinya kepada Allah dengan mengikuti berbagai kajian ataupun kegiatan- kegiatan yang diselenggarakan komunitas hijrah (Hasbiansyah, 2018).

Sabagai upaya dalam mengantisipasi kenakalan remaja yang semakin merajalela, diperlukan sebuah gebrakan yang sesuai dengan usia remaja, yang bisa dengan mudah masuk dan diterima dikalangan remaja, oleh karena itu akhir- akhir ini menjadi 
perbincangan hangat di masyarakat indonesia tentang sebuah gerakan perubahan terhadap generasi muda yang kekinian. Shift lahir untuk pemuda Indonesia yang membutuhkan dan merindukan dakwah yang kekinian. Oleh karena itu tema hijrah yang diangkat ditujukan untuk memberi solusi permasalahan bagi anak muda. Dan permasalahan anak muda itu sendiri tidak jauh- jauh dari masalah cinta, karir, hiburan, sosial dan keluarga. Sehingga konten yang disajikan memang didesain unuk kalangan anak muda serta menyesuaikan dengan permasalahan- permasalahan yang dihadapi. Selain itu judul yang diangkat juga menggunakan bahasa anak muda seperti "jangan kasih kendor" "woles aja" "geer" dan lain sebagainya (GenM, 2017).

Hijrah ini juga tidak hanya bersifat sebagai dakwah yang monoton dalam penyampain yang selalu diakitkan dengan dosa pahala tetapi lebih sedikit leluasa dalam artian menggunakan bahasa yang lebih kekinian. Karena konteks yang dibawakan merupakan pengalaman tentang pembebasan, baik secara historis maupun spiritual dalam arti kata memberikan ruang yang luas pada generasi muda dalam berkarya sekereatif mungkin dan bergaya mengikuti tren yang kekinian, tetapi tetap pada nilai nilai religiusitas serta syar'I (Ramadhan, 2007).

Hijrah yang dimaksudkan adalah kembali pada kehidupan yang beragama, berusaha menaati perintah Allah, menjauhi larangannya. Hijrah mempunyai definisi secara syar'i berawal pada peristiwa hijrah (migrasi) Rasulullah dari Mekah ke Yatsrib (yang kemudian hari diubah namanya menjadi Madinah) dalam upaya menyelamatkan dakwah Islam dari gangguan kafir Quraisy yang memiliki perluasan makna yaitu meninggalkan segala bentuk kemaksiatan dan kemungkaran, baik dalam perasaan (hati), perkataan dan perbuatan. Hijrah memiliki makna ruhiyah, yaitu seseorang yang meninggalkan perbuatan maksiat dan tidak menoleh pada hal-hal yang menyebabkan Allah (Muhamamd, 2004).

\section{Metode Penelitian}

Dalam penelitian ini peneliti menggunakan metode kualitatif. Menurut Denzim dan Lincoln dalam Herdiansyah penelitian kualitatif bertujuan untuk menyediakan penjelasan tersirat mengenai struktur, tatanan, dan pola yang luas yang terdapat dalam suatu kelompok partisipan (Herdiansyah, 2011). Penelitian ini menggunakan pendekatan fenomenologi untuk menggali makna lebih dalam tentang hijrah pada anggota komunitas Hijrah yuk ngaji Yogyakarta, di mana dunia persepsi menjadi titik tolak dari pemikiran fenomenologi.

Fenomenologi transendental dirintis oleh Edmund Husserl, melalui pendekatan fenomenologi eksistensial yang dia teliti dari transendentalisme. Husserl mengungkapkan bahwa dalam kehidupan sehari-hari, orang mengalami sesuatu sejenis sikap ilmiah- yang dipengaruhi oleh kepercayaan ataupun prasangka. Namun, dalam cara hidup alamiah tidak ada disiplin yang mencukupi untuk memungkinkan adanya pengetahuan sejati. Untuk mempelajari sebuah topik secara fenomenologis, seseorang dituntut untuk dapat memilah-milah fenomena, yang akhirnya memungkinkan untuk dapat berlangsungnya sebuah penelitian fenomenologis (Syam, 2011). Dalam metode fenomenologi, setelah ada sebuah topik kemudian mengumpulkan data yang cukup. Pemilihan fenomena-fenomena yang akhirnya memungkinkan untuk berlangsungnya sebuah penelitian fenomenologis, istilahnya disebutkan oleh Husserl 
adalah reduksi fenomenologis atau epoche (Syam, 2011). yang merupakan eliminasi secara hati- hati dan sistematis dari faktor subjektif yang masuk dalam pengalaman murni seseorang tentang sesuatu.

Dalam reduksi, orang memilah faktor-faktor subjektif, termasuk sejarah, bias dan kepentingan, untuk menghapuskan elemen-elemen pengganggu ini dan berkonsentrasi pada objek yang diamati. Sebuah kesadaran murni akan objek tersebut akan mengungkap esensi yang sesungguhnya. Setiap fenomena memiliki sebuah esensi murni yang akan disetujui keberadaanya oleh pengamat yang disiplin. Melalui metode ini, maka esensi murni dari sebuah fenomena lebih berfokus pada ilmu pengetahuan tentang bagaimana lebih mengenal Tuhan, dimana tujuan utamanya adalah merasa dekat, merasa melihat atau dilihat Tuhan. Karena setelah kumpulan peristiwa berhasil direduksi, dalam metode fenomenologi, maka reduksi selanjutnya yaitu transendental bisa dibuat, sehingga secara otomatis reduksi ini akan memilah pengalaman itu sendiri.

Memahami metodologi fenomenologi, akan lebih jelas dengan mengikuti pemikiran Schutz. Seperti telah dikemukakan sebelumnya, dialah yang pertama kali membuat penelitian sosial berbeda dari pendahulunya, yang berorientasi positivistik. Walaupun pelopor fenomenologi adalah Husserl, Schutz adalah orang pertama yang menerapkan fenomenologi dalam penelitian ilmu sosial. Itulah sebabnya, dalam pembahasan metodologi fenomenologi, Schutz mendapatkan prioritas utama. Selain itu, melalui Schutz pemikirin-pemikiran Husserl yang dirasakan abstrak pada masa itu dapat dimengerti. Subjek penelitian ini adalah pemuda hijrah pada komunitas Yuk Ngaji Yogyakarta. Subjek dipilih secara purposive berdasarkan aktivitas bersama komunitas pemuda hijrah, kesediaan mereka untuk mengeksplorasi dan mengartikulasikan pengalaman mereka secara sadar. Dalam penelitian ini, peneliti mewawancarai lima orang narasumber sebagai informan utama, setelah sebelumnya mewawancarai beberapa orang yang terlibat dalam komunitas pemuda hijrah.

\section{Hasil}

Gerakan pemuda hijrah merupakan gerakan dakwah yang berada di bandung. Terbentuk pada bulan Maret tahun 2015 hasil pemikiran seorang Ustadz Tengku Hanan Attaki, Lc. Beliau bersama rekannya membentuk gerakan Pemuda Hijrah dengan harapan dapat memberikan wadah (tempat) bagi orang- orang yang ingin berhijrah mendekatkan diri kepada Allah Swt., dengan belajar dan memahami ilmu agama Islam (Solihat, 2016). Saat ini kata hijrah menjadi fenomena yang cukup besar dalam kehidupan khususnya umat Muslim. Yaitu menjadikan diri menjadi lebih baik dari sebelumnya, menunjukkan bahwa diri telah taubat, mendekatkan diri dengan Tuhan, menjalankan syari'at Islam secara lahiriah maupun bathiniah. makna lain dari hijrah ini sebagai usaha menjauhkan diri dari berbagai bentuk penyimpangan menuju aturan yang lebih baik dan konsisten. Adapun secara historis hijrah merupakan tindakan pragmatis monumentalis yang bermakna nilai- nilai normative (Aswadi, 2011). Hijrah ini menjadi sebuah gaya hidup dalam masyarakat terlebih dikalangan pemuda. Dapat dilihat dari terselenggaranya beberapa kajian yang diadakan, pemuda lebih cenderung mendominasi. Ini memperlihatkan kajian islam memang bukan diperuntukkan untuk generasi tua, melainkan untuk seluruh generasi muslim. 
Berhijrahnya seseorang dari hal-hal negatif menuju ketaatan kepada Allah membuktikan bahwa manusia sejauh mana mereka mengingkari Tuhannya dan tidak menjalankan perintah-NYA tetap mereka akan membutuhkan agama untuk menuntun kehidupannya, seperti yang diungkapkan oleh Ramayulis dalam bukunya psikologi agama mengenai manusia memiliki kebutuhan yang penting dalam kehidupannya yaitu kebutuhan akan keagamaan walaupun tidak disadarinya sehingga hal tersebut membuat manusia disebut sebagai makhluk beragama (Homo Religius) (Ramayulis, 2013). Maka gerakan pemuda hijrah berperan aktif dalam mengajak orang- orang khususnya anak muda semakin dekat dengan Allah Swt., dan membuat mereka tidak hanya terlihat gaul dihadapan manusia tetapi juga dekat dengan Allah Swt.

Tujuan hidup bagi anggota Pemuda Hijrah, yaitu akhirat. Adapun yang menjadi tujuan kematian adalah mempertanggungjawabkan apa yang dilakukan di dunia dan menjadikan tujuan kematian adalah awal kehidupan abadi. Adapun hubungan dengan Allah Swt lebih terasa dekat pascaberhijrah. Ketika berhijrah, pola beribadah lebih mengutamakan yang wajib dibanding yang sunah dan kini lebih tawakal dalam menghadapi musibah. Mereka dulu mengenal Islam sebagai agama yang ribet, sulit, dan lebay. Namun kini, mereka mengenal Islam menjadi agama yang sempurna dan membawa mereka ke surga.

"Secara spiritual rasa bertanggungjawab itu ditekankan pada anggota komunitas, karena memang tujuan yang ingin dicapai dalam kehidupan ini adalah kebahagiaan dunia dan Akhirat, terlebih untuk menghadapi akhirat kelak, kehidupan dunia ini menjadi sebuah pertanggung jawaban nantinya dihadapan Tuhan, untuk menghadapi semua itu mengutamakan semua kewajiban dari Allah adalah hal terpenting yang harus mereka jalankan namun dalam menjalankannya mereka tetap di anjurkan aktif dalam bersosial" (hasil wawancara dengan Zulkarnain, Yogyakarta 10 Agustus 2019).

Berdasarkan keterangan ini dapat dikatakan bahwa para pemuda hijrah yang mengikuti komunitas hijrah Yuk Ngaji Yogyakarta ini memang diberikan pencerahan terhadap kehidupan yang akan dialami setelah kematian nantinya, hali ini adalah sebuah cara penyampaian rasa bertangnngungjawab untuk setiap aktivitas yang dilakukan selama hidup didunia. Kehidupan didunia memang tidak hanya seutuhnya selalu menggambarkan akan hari akhirat tetapi juga sikap sosial terhadap lingkungan masyarakat diperlukan, selain hakekatnya manusia sebagai makhluk sosial yang membutuhkan satu dengan yang lainnya ini juga akan dipertanggung jawabkan nantinya di akhirat.

Sebagai tindak lanjut dari tujuan hidup yang disampaikan pada komunitas pemuda hijrah, kegiatan- kegiatan yang menunjang hal itu juga dilakukan dengan berbagai hal. Seperti pengajian yang rutin dilaksanakan setiap hari Jum'at setiap dua minggu sekali, acara seminar, workshop yang menampilkan para pembicara- pembicara muda dan modren yang tentunya sesuai dengan keinginan anak muda sekarang. Hal tersebut disampaikan oleh Zulkarnain selaku staf humas komunitas:

"Untuk mendukung apa yang menjadi sebagai tujuan dari pemuda hijrah ini, diadakannya kegiatan- kegiatan yang mendukung hal tersebut, seperti pengajian yang rutin diadakan setiap dua minggu sekali, dengan tema-tema yang kekinian 
yang cocok untuk anak muda, selain itu juga seminar atau workshop juga sering dilakukan dengan mendatangkan ustad atau pembicara milenial yang dapat mewakili hati kaula muda, sehingga diharapkan mereka dengan mudah dapat menerima apa yang disampaikan(wawancara dengan staf komunitas hijrah Yuk Ngaji Yogyakarta 10 Agustus 2019).

Dari beberapa bentuk kegiatan tersebut dengan judul yang kekinian dapat begitu mudah diterima oleh kalangan anak muda dan dan menarik minat mereka untuk tetap berpartisipasi dalam kegiatan tersebut. Tema ceramah maupun seminar yang tidak monoton juga mampu memberikan efek positif terhadap pemuda komunitas hijrah, dalam hal ini dapat dilihat dari pengakuan anggota komunitas:

"Saya merasa hidup lebih nyaman, tenang dan semakin mudah dalam melaksanakan kewajiban terhadap Allah Swt., contoh sederhananya saja dulu sebelum saya ikut komunitas ini shalat saya selalu bolong- bolong, kadang lagi rajin shalat kalau lagi malas shalat ditinggalkan dan perasaan saya saat itu biasa saja, namun setelah saya masuk dan aktif dalam komunitas ini saya mulai rajin melaksanakan shalat, merasa ada yang kurang jika meninggalkan shalat serta merasa diri lebih terjaga dari perbuatan- perbuatan yang tidak baik"(wawancara dengan Herlambang salah satu anggotanggota komunitas Hijrah Yuk Ngaji Yogyakarta, 15 Agustus 2019)

Pengakuan ini disampaikan oleh salah seorang anggota komunitas, dari pengakuannya ia mendapatkan perubahan pada dirinya menjadi lebih baik dan bersikap positif, kesalehan semakin bertambah rasa tangung jawab terhadap apa yang dilakukan juga semakin tumbuh, hal ini dapat di lihat dari keterangannya bahwa ada rasa takut ketika ingin melakukan perbuatan yang tidak sesuai dengan syari'at Islam.

Tahap selanjutnya setelah berusaha menjadikan segala kegiatan positif menjadi kebiasaan adalah menjaga diri agar tetap istiqamah. Hal ini termasuk sulit untuk melakukannya, dikarenakan keseharian para anggota pemuda hijrah ini lebih dominan berada dalam lingkungan yang dapat dianggap bebas terkadang lupa mengontrol diri dan lalai untuk melaksanakan kewajiban. Tetapi dengan adanya ceramah- ceramah oleh para ustad yang selalu setia mengingatkan dan memberikan motivasi untuk tetap istiqamah berada dalam jalan Allah Swt., keimanan yang bisa saja naik- turun dengan sendirinya lebih merasa bahwa ada yang mengawasi.

"Sebenarnya mengikuti komunitas Hijrah ini sangat asik, selain dapat menjadikan diri lebih shaleh saya juga mendapat teman- teman yang baru. Namun waktu yang tidak full time dengan kawan- kawan satu komunitas atau yang tidak satu jalan pemikiran terkadang bisa saja lalai, Menjaga agar tetap Istiqomah ini sangat sulit, tapi untungnya setiap dua kali seminggu yang rutin ada pengajian, jadi ada ustad yang selalu mengingatkan agar tetap istiqomah. Jadi dengan sendirinya atau istilahnya mungkin Imannya kembali di refresh agar lebih segar gitu ( hasil wawancara dengan Adin salah seorang anggota Komunitas pada 15 Agustus 2019).

Dari beberapa wawancara dengan pengurus komunitas serta pemuda yang mengikuti komunitas ini dapat dilihat bahwa upaya yang dilakukan Komunitas Hijrah ini untuk menjadikan generasi muda yang berakhlak, shaleh dan tetap aktif dalam dunia 
modren bisa dikatakan berhasil. Ini dapat dilihan dari pengakuan dari beberapa anggota komunitas yang telah diwawancarai, dan memberikan pengakuan bahwa kehidupan dirinya lebih baik setelah mengikuti kegiatan- kegiatan yang dilakukan oleh komunitas hijrah Yuk ngaji Yogyakarta.

Dari sikap yang lebih baik yang dirasakan oleh anggota pemuda hijrah ini, peneliti juga mengamati bagaimana gaya hidup mereka untuk melihat apakah hijrah mereka sebagai keshalehan atau hanya sekedar gaya hidup untuk mengikuti tren kekinian. Gaya hidup modren yang kekinian tidak terlepas dari anak muda yang tidak mau ketinggalam update dengan gaya terbaru, terutama dalam berbusana, sebagai seorang yang berada dalam komunitas Islami tentu ada beberapa aturan yang boleh atau tidak untuk dipakai dalam berbusana.

"kalau dari berbusana kami tidak ditekankan harus memakai busana yang serti ini atau itu, tetapi hanya di sampaikan bahwa hberbusana dengan syariat islam lebih baik yakni selalu menutup aurat (wawancara dengan Henri anggota Komunitas Hijrah Yuk ngaji Yogyakarta tanggal 16 Agustus 2019).

Dari pengamatan peneliti melihat cara berbusana mereka dalam melaksanakan kegiatan sehari- hari sangat baik, dalam artian menutup aurat sesuai dengan syariat islam, untuk yang ikhwan peneliti melihat mereka sangat Pashionable dalam berpakaian, mengikuti tren pakaian syar'i yang kekinian begitu juga dengan akhwat yang terlihat pashionable mengikuti syariat.m Hasil penemuan penelitian bahwa komunitas Hijrah ini memberikan dampak positif bagi anak muda, kegiatan - kegiatan serta aktivitas keislaman yang dilakukan dapat menarik minat para generasi muda di era milenial ini. Dengan adanya komunitas Hijrah ini peneliti mengamati bahwa hal ini merupakan gerakan yang sangat bagus untuk generasi muda kedepannya.

\section{Pembahasan}

Fenomena yang menarik di JCC Jakarta, dimana "hijrah" dijadikan ajang festival dan sukses luar biasa sehingga menimbulkan viral di mana-mana. Namanya, Hijrah Fest 2018. "hijrah" kini menjadi sesuatu yang happening, heboh, dan keren, sehingga perlu difestivalkan (GenM, 2017) Hijrah Fest sesungguhnya bukanlah fenomena yang datang tiba-tiba. Sejak 10 tahun lalu, kalangan milenial muslim mulai mendapatkan identitas baru yang keren.. Contohnya, dulu di pertengahan tahun 2000-an muncul tren musik, sinetron, dan film Islam yang begitu heboh. Di film misalnya, dipicu sukses Ayat-Ayat Cinta (2008), film-film bertema Islam menjadi booming dan menjadi identitas budaya pop baru yang universal. Artinya tidak hanya disukai oleh kaum muslim saja, tapi oleh semua kalangan masyarakat (GenM, 2017), kemudian menjelang tahun 2010-an, tibatiba hijab fashion menjadi tren kaum muslimah urban yang cool (sering disebut "hijabers lifestyle". Tren ini memicu gelombang revolusi industri hijab di tanah air.

Gerakan pemuda hijrah merupakan gerakan dakwah yang berada di bandung. Terbentuk pada bulan Maret tahun 2015 hasil pemikiran seorang Ustadz Tengku Hanan Attaki, Lc. Beliau bersama rekannya membentuk gerakan Pemuda Hijrah dengan harapan dapat memberikan wadah (tempat) bagi orang- orang yang ingin berhijrah mendekatkan diri kepada Allah Swt., dengan belajar dan memahami ilmu agama Islam. 
Gerakan ini terbentuk dari sebuah kegelisahan Ustadz Hanan Attaki yang merasa bahwa dakwah di Indonesia kurang progresif atau jalan ditempat, terlebih untuk kalangan anak muda. Dakwah di Indonesia cenderung terjebak dalam kegiatan-kegiatan dimana para jamaahnya memang sudah hijrah sejak lama, sehingga penambahan orang-orang yang kemudian mendapat hidayah, sadar dan kembali kepada Allah itu sedikit walaupun kegiatanya banyak. Padahal sebenarnya banyak anak muda yang membutuhkan dakwah dan merindukan hidayah, hanya saja tidak tahu caranya. Anak muda merupakan orangorang yang memiliki peran besar dimasa mendatang, jika saat ini generasi muda mulai hancur, bisa kita bayangkan bagaimana kondisi Indonesia dimasa depan.

\section{A. Hijrah sebagai Kesalehan}

Tujuan hidup bagi anggota Pemuda Hijrah, yaitu akhirat. Adapun yang menjadi tujuan kematian adalah mempertanggungjawabkan apa yang dilakukan di dunia dan menjadikan tujuan kematian adalah awal kehidupan abadi. Adapun hubungan dengan Allah Swt lebih terasa dekat pascaberhijrah. Ketika berhijrah, pola beribadah lebih mengutamakan yang wajib dibanding yang sunah dan kini lebih tawakal dalam menghadapi musibah. Mereka dulu mengenal Islam sebagai agama yang ribet, sulit, dan lebay. Namun kini, mereka mengenal Islam menjadi agama yang sempurna dan membawa mereka ke surga.

Secara spiritual, yang dirasakan oleh para informan adalah memulai dengan disiplin untuk bangun shalat subuh. Tadinya kegiatan ini merupakan hal sulit dilakukan. Namun, seiring proses hijrah spiritual ini, dari kepribadian mereka sendiri merasakan bisa sering bangun subuh, shalat tepat waktu, dan lama-kelamaan menjadi kebiasaan. Tahap selanjutnya, setelah berusaha menjadi kebiasaan, adalah menjaga agar istiqamah. Pada awalnya, mereka merasakan cukup sulit apalagi lingkungan tidak mendukung. Frekuensi rajin ikut kajian masih dipengaruhi oleh pengaruh kebersamaan teman-teman. Namun demikian, ustad yang mengisi kajian tersebut memotivasi untuk menjaga keistiqomahan dalam beribadah, meskipun di sisi lain juga diingatkan bahwa mereka masih muda jadi godaan- godaan juga banyak. Jadi sangat wajar iman pemuda itu naik turun.

Pengalaman hijrah spiritual juga berasal dari permasalahan kehidupan masingmasing yang merasa bahwa hidup hanya berjalan begitu saja. Ada masalah keluarga yang melanda tapi tidak menemukan solusi. Ada ruang spiritual yang hampa yang mereka rasakan. Setelah proses hijrah dan memaknainya lebih dalam, mereka merasakan bahwa kehadiran Allah, keterlibatan Allah dalam segala aspek kehidupan membuat lebih tenang dalam memaknai hidup serta lebih berhati - hati dalam menjalankan kehidupan sehari- hari.

\section{B. Hijrah Gaya Hidup}

Dalam penelitian ini informan memaknai hijrah dengan perubahan ke arah yang lebih baik sebagai makna umum dari makna hijrah itu sendiri. Adapun secara personal, mereka merasa bahwa ada perubahan baik dari segi berpakaian maupun ketaatan dalam melaksanakan ibadah ketika sudah berhijrah. Alasan keingin melakukan proses hijrah adalah takut akan neraka dan merasa sudah dekat. Pada dasarnya, informan mementingkan unsur perubahan fisik terlebih dahulu dalam berhijrah, Untuk informan laki-laki (ikhwan), mereka mengubah penampilan diawali 
dengan menggunakan celana jeans yang sesuai dengan anak muda zaman sekarang, dan mereka lebih sering mengenakan kemeja. Mereka tampil lebih Fashionable dari biasanya tetapi tetap sesuai dengan syari'at islam.

Pada dasarnya, informan merasa bahwa penampilan syar'i adalah kewajiban dari Allah Swt dan merupakan suatu identitas bagi kaum Muslim. di samping itu, para informan setelah memenuhi syariat Islam dalam berpakaian mereka juga membuat perkumpulan di cafe- cafe mengikuti kebiasaan anak muda lainnya, hanya saja mereka lebih menekankan pada diskusi keseharian serta hal- hal yang dapat meningkatkan ketakwaan diri. dalam berpakaian ataupun gaya hidup sehari- hari, mereka tetaplah sama dengan pemuda lainnya, tidak ada perbedaan yang signifikan, hanya saja dalam berkomunikasi mereka lebih santai, sopan dan kalem.

\section{Kegiatan pendukung pencapaian tujuan komunitas}

Untuk mewujudkan kesalehan terhadap para anggota komunitas kegiatan yang mendukung diadakan secara rutin dan konsisten, ada beberapa kegiatan yang langsung bersinggungan dengan para anggota komunitas Hijrah untuk mencapai tujuan dari berdirinya komunitas:

1. Pengajian keagamaan

Pengajian keagamaan merupakan aktivitas rutin yang dilaksanakan untuk mendukung tercapainya tujuan komunitas, berbagai macam kegiatan yang diikuti oleh para anggota komunitas pemuda hijrah diantaranya ceramah keislaman, seminar agama serta workshop.

a. Ceramah keagamaan

Ceramah keagamaan dibalut semenarik mungkin disesuaikan dengan karakter anak muda zaman sekarang, mulai dari pengambilan judul yang didesain dengan anak muda dan bergaya milenial seperti ceramah yang diadakan pada 15 agustus 2019 I am single and Very Happy bersama Ust Ransi Al- Indragiri. Tema yang diambil ini sangat kekinian sekali bahasanya anak milenial hal ini di rencanakan sedemikian rupa dengan harapan pemuda tertarik untuk mempelajari Islam dan memberikan pemahaman bahwa Islam itu tidak ketinggalan zaman.

Isi dalam ceramah tersebut menggambarkan bahwa pemuda yang baik adalah mereka yang tidak berputus asa walaupun sendirian, mereka yang tidak merasa sendirian tanpa pacar, mereka tetap merasa bahagia tanpa kekasih bagaimana para generasi milenial yang disibukkan dengan urusan berpacaran, namun mereka lebih memaknai bahwa tiada kesendirian dalam kehidupan karena ada Allah yang selalu menemani dalam setiap aktivitas kehidupan.

b. Seminar Keislaman

Hampir sama dengan ceramah keislaman seminar ini konteksnya sedikit luas yakni kegiatannya bisa diikuti oleh masyarakat umum, dan judul yang 
diambil juga dalam acara ini lebih umum, karena dikondisikan dengan peserta yang mengikuti seminar.

2. Program keislaman

Program - program yang dibuat di untuk menarik minat dan menetapkan para anggota komunitas hijrah ini di desain semodren mungkin dalam balutan nilai keislaman, apa yang biasanya dilakukan oleh anak muda zaman milenial ini dijadikan sebagai program yang didalamnya tersirat nilai nilai keislaman, hag out misalnya atau ngopi bareng menjadi program yang di adakan dalam mengisi keiatan atau pada event tertentu. Hal ini membuat anggota komunitas semakin tertarik dengan kajian - kajian islam yang ada dalam progam komunitas.

\section{Kesimpulan}

Hijrah dimulai dengan hijrah penampilan fisik, dari cara berpakian dan penampilan, karena penampilan merupakan suatu identitas. Untuk pergaulan seharihari, mereka mulai menghindari pergaulan dengan lawan jenis dan kegiatan-kegiatan yang melalaikan dalam keseharian tentunya dengan cara akhlaq yang baik. adapun yang menjadi tujuan mereka adalah mempertanggungjawabkan apa yang dilakukan di dunia dan menjadikan tujuan kematian adalah awal kehidupan abadi. Mereka pun lebih tawakal dalam menghadapi musibah. Memaknai Islam yang tadinya rumit, sulit, menjadikan Islam sebagai agama yang sempurna dan membawa mereka ke surga, kebahagiaan yang kekal di akhirat.

\section{Referensi}

Aswadi, A. (2011). Refomulasi Epistemologi Hijrah dalam Dakwah. ISLAMICA: Jurnal Studi Keislaman 5, no. 2, 339-353.

Fitri, S. (2017). Dampak positif dan negatif sosial media terhadap perubahan sosial anak. Naturalistic: Jurnal Kajian Penelitian Pendidikan dan Pembelajaran 1, no. 2, 120.

GenM, Y. d. (2017). Cetakan pertama . Yogyakarta: Bentang.

Hasbiansyah, L. T. (2018). Aktivitas Dakwah Komunitas The Shift Gerakan Pemuda Hijrah. Prosiding Manajemen Komunikasi o, no. o, (p. 123).

Herdiansyah. (2011). Metodologi Penelitian untuk Ilmu-ilmu Sosial . Jakarta: Salemba Humanika.

Muhamamd, A. A. (2004). Strategi hijrah: prinsip-prinsip dan ilmiah tuhan. Tiga Serangkai.

Muzayanah, U. (2018). Tren Beragama Remaja Era Milenial: Analisis Perilaku Siswa SMA di Jawa Tengah. FIKRAH $6,263$.

Nisfiannoor, V. V. (2016). Identity achievement dengan intimacy pada remaja SMA. Jurnal Provitae 2, no. 1, 215.

Rais, U. F. (2018). Pengelolaan Kesan Da’i dalam Kegiatan Dakwah Pemuda Hijrah. KOMUNIKA: Jurnal Dakwah Dan Komunikasi, 12, no. 2 , 212.

Ramadhan, T. (2007). Muhammad Rasul Zaman Kita . Jakarta: Penerbit Serambi.

Ramayulis. (2013). Psikologi Agama . Jakarta: Kalam Mulia. 
Solihat, I. (2016). Strategi komunikasi persuasif pengurus gerakan pemuda hijrah dalam berdakwah . Jakarta: B.S. thesis: Fakultas Ilmu Dakwah dan Ilmu Komunikasi UIN Syarif Hidayatullah.

Sudargo, T. (2018). 1000 hari pertama kehidupan . Yogyakarta: Gadjah Mada University Press.

Syam, N. W. (2011). Komunikasi Trasendental: Perspektif Integrated Science. Bandung: NWS Publishing. 